\title{
Changes in quantity and quality of organic matter in soil after application of poultry litter and poultry litter biochar-5-year field experiment
}

\author{
Renata Jarosz ${ }^{1}$ (D) Monika Mierzwa-Hersztek ${ }^{1,2}$ (D) Krzysztof Gondek $^{2}$ (D) $\cdot$ Michał Kopeć $^{2}$ (D) Tomáš Lošák $^{3} \cdot$ \\ Lidia Marcińska-Mazur ${ }^{2}$
}

Received: 18 June 2020 / Revised: 1 September 2020 / Accepted: 10 September 2020 / Published online: 25 September 2020

(C) The Author(s) 2020

\begin{abstract}
Changes of the addition of poultry litter (PL) and poultry litter biochar (PLB) on quantitative and qualitative humus parameters in loamy sand were estimated during the 5-year study period. The following properties were determined in soil: $\mathrm{pH}$, total carbon (Ctotal), total nitrogen (Ntotal), humic and fulvic acids, extracted carbon, and non-hydrolysing carbon. Additionally, light absorbance in the solutions of humic acids was computed at the wavelength of 280,465 , and $665 \mathrm{~nm}$. It was demonstrated that organic matter mineralisation was most intense in soil with the addition of PL, causing significant quantitative and qualitative changes in humus compounds in soil. A slower rate of organic matter mineralisation was observed in soil amended with PLB, especially in a dose of $5.0 \mathrm{t} \mathrm{ha}^{-1}$, which indicated the long-term effect of this material on improving soil properties. Spectrophotometric indexes for the solution of humic acids also showed that PLB had a more favourable effect on the structure durability and lower mobility of humic acid carbon compared with PL. The application of PL and PLB significantly increased the non-hydrolysing carbon content in soil, indicating greater stabilisation of humus compounds and, at the same time, lower $\mathrm{CO}_{2}$ emissions. It was found that the addition of organic materials to soil significantly increased the soil organic carbon contents. Our study has shown that the identification of changes that may occur in the quantitative and qualitative composition of soil humus after the application of PLB may be helpful in determining the appropriate biochar dose.
\end{abstract}

Keywords Soil $\cdot$ Humic substances $\cdot$ Biochar $\cdot$ Organic carbon $\cdot$ Carbon stocks

\section{Introduction}

Soil organic matter (SOM) has a positive effect on soil sorption and buffering properties and biological activity; it stabilises soil structure, consequently limiting its degradation [1]. Due to the multi-directional, beneficial effects of organic

Monika Mierzwa-Hersztek

monika6_mierzwa@wp.pl; monika.mierzwa@urk.edu.pl

1 Department of Mineralogy, Petrography and Geochemistry, AGH University of Science and Technology, Al. Mickiewicza 30, 30-059 Krakow, Poland

2 Department of Agricultural and Environmental Chemistry, University of Agriculture in Krakow, Al. Mickiewicza 21, Krakow 31-120, Poland

3 Department of Environmentalistics and Natural Resources, Mendel University in Brno, Zemědělská 1/1665, 613

00 Brno, Czech Republic matter in soil, solutions that could improve soil richness in SOM have been sought for many years. Application of various organic materials, including waste, is one of the activities potentially increasing OM resources.

Undoubtedly, a significant amount of organic waste is generated on farms and during processing of poultry feedstock. In Poland, the poultry industry is one of the fastest growing segments of the domestic agri-food sector. Poland is a significant poultry producer in Europe and in the world. It is estimated that the production of poultry livestock in Poland in 2018 amounted to over 3.5 million tonnes and was by $4.4 \%$ higher than in 2017 [2]. Therefore, the poultry industry development generates more and more organic waste, including significant amounts of poultry litter. Maintaining the current pace of poultry production requires limiting the negative effect of farms on the environment and increasing farmers' awareness of how to manage faeces and waste from poultry farms [3]. Improper application of poultry litter directly to the soil may pose both chemical and biological hazards to the environment 
[4]. Poultry litter is rich in many components that can be dispersed in the environment; for instance, they can be leached into groundwater or cause soil salinity. Due to the possible presence in poultry litter of, among others, pathogenic microorganisms, the material is likely to create health risks. Environmental problems may also result from the storage of poultry litter for several months, releasing a significant load (e.g., of ammonia) into the atmosphere [5]. Considering the above hazards, thermal conversion processes, such as pyrolysis, become a safe alternative for the environmental application of materials alike [1].

According to Shakya and Agarwal [6], thermal processing of poultry litter increases its stability and safety for human health. The physical properties of the converted feedstock, e.g., specific surface area, are also positively affected [7]. The thermal conversion of poultry litter to biochar facilitates the material storage and is a very important direction of environmental resource retardation.

Biochar is carbon-rich material produced from the pyrolysis of biomass feedstock materials under partial or total absence of oxygen $[8,9]$. Biochar consists mainly of C (50-90\%), volatile substances $(0-40 \%)$, and mineral substances $(0.5-5 \%)$. Biochar has a porous carbon structure, containing nano-scale condensed aromatic rings for high specific surface area. Generally, biochar derived from high-temperature pyrolysis is characterised by a large surface area and aromatic carbon content, which may increase the adsorption capacity (a desirable property for bioremediation) as well as the recalcitrant character (for carbon sequestration) [10]. The physical parameters are strongly related to the type of the initial feedstock used and pyrolysis conditions (i.e., temperature, residence time, and pressure). In most cases, as the temperature increases, the specific surface area, pore volume, $\mathrm{pH}$ value, and cation exchange capacity increase and, in turn, the contents of volatile elements such as $\mathrm{C}, \mathrm{N}$, and $\mathrm{S}$ decrease [10-12]. The chemical composition of biochar is stable, and it shows low susceptibility to degradation and microbiological decomposition.

As stated by Jeffery et al. [13] and Yusof et al. [14], application of biochar to soil increases the nutrient content for plants, promotes $\mathrm{C}$ sequestration in soil, supports water retention, and increases the microbial activity, soil sorption capacity, and heavy metal ion immobilisation. Biochar is widely recognised as an efficient tool for carbon sequestration and reduces nitrous oxide $\left(\mathrm{N}_{2} \mathrm{O}\right)$ emission and $\mathrm{CH}_{4}$ emission [8, 9]. Chemically stable $\mathrm{C}$ fractions of biochar contribute to the soil $\mathrm{C}$ sequestration and may have an important role for the global $\mathrm{C}$ budget. The relative amount of recalcitrant and labile compounds and the degree to which the organic compounds are protected from decomposition determine soil organic matter degradability after biochar addition [7]. In addition, taking into account biochar ageing in soil and the resulting changes in its properties, it is fully justified and necessary to monitor the material effect on soil properties in experiences conducted for many years. There are also data reporting no significant change or even negative effects after biochar application [15]. Also, it should be emphasised that the number of studies on the effect of biochar on the humus compound transformation is very small. Considering the constantly increasing interest in biochar in the context of improving soil fertility and productivity, it is very important to assess the effect of this material on the quantitative and qualitative transformations of humus compounds in soil. This study hypothesises that the application of biochar from poultry litter together with mineral fertilisation stabilises the quantity and quality of humus compounds in soil, promoting the long-term $\mathrm{C}$ storage in it.

\section{Materials and methods}

\subsection{Experiment location}

The experimental field was located in southern Poland $\left(50^{\circ}\right.$ $08.404^{\prime} \mathrm{N} ; 19^{\circ} 85.362^{\prime} \mathrm{E}$ ), and the experiment was carried out in the years 2014-2018 (five growing periods). The microplot area was $1 \mathrm{~m}^{2}$. The soil in the experiment location was qualified as typical Eutric Cambisols with the granulometric composition of loamy sand (FAO World Reference Base for Soil Resources 1998). The field experiment was established in the spring of 2014 at the Experimental Station of the Agricultural University in Krakow. Laboratory analyses of the study material were carried out at the Department of Agricultural and Environmental Chemistry at the University of Agriculture in Krakow.

\subsection{Climate conditions}

The total annual precipitation in 2014 was $639 \mathrm{~mm}$. The highest precipitation was recorded in May $(110 \mathrm{~mm})$, July $(100 \mathrm{~mm})$, and August $(97 \mathrm{~mm})$, while the lowest in 2014 occurred in February $(17 \mathrm{~mm})$ and December $(23 \mathrm{~mm})$. In 2018, the total annual precipitation was $672 \mathrm{~mm}$. The highest precipitation was recorded in January $(95 \mathrm{~mm})$ and July (93 $\mathrm{mm})$, while the lowest in February $(10 \mathrm{~mm})$, April $(13 \mathrm{~mm})$, and March $(16 \mathrm{~mm})$. The average temperatures in 2014 ranged from -0.9 in January to $17.5^{\circ} \mathrm{C}$ in July, while in 2018 , the lowest average monthly temperature of $-3{ }^{\circ} \mathrm{C}$ was recorded in February, and the highest of $20.6{ }^{\circ} \mathrm{C}$ in August. The air temperatures and precipitations are shown in Fig. 1. Meteorological conditions were recorded using an automatic meteorological station located in Krakow Mydlniki.

\subsection{Pyrolysis process and properties of soil, poultry litter, and poultry litter biochar}

The pyrolysis process was carried out at a station designed for biomass conversion, under a limited supply of air (1-2\%). Temperature in the combustion chamber was $300 \pm 10^{\circ} \mathrm{C}$, and 
Fig. 1 Climatic conditions in the experiment location from 2014 to 2018

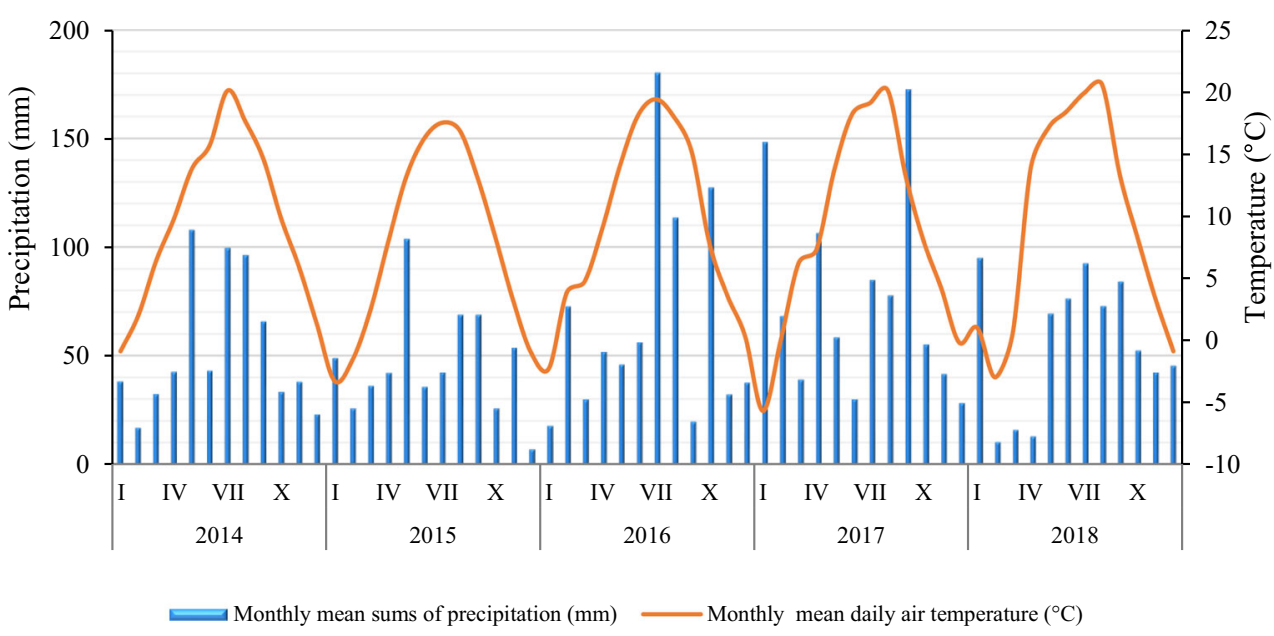

exposure time was $15 \mathrm{~min}$. The process parameters have been configured so that Ctotal losses are as low as possible. The quality of poultry litter biochar depends on the peak pyrolysis temperature. To obtain biochar from poultry litter for agricultural purposes, pyrolysis at $300{ }^{\circ} \mathrm{C}$ is recommended, since the resulting biochars feature, among other things, higher cation exchange capacity and increased content of carbon compounds [16]. Additionally, biochars produced at a temperature above $300{ }^{\circ} \mathrm{C}$ contain a much smaller quantity of aliphatic carbon compounds and functional groups, which may significantly reduce the effectiveness of these materials in improving the soil quality [17]. Increasing the temperature above $500{ }^{\circ} \mathrm{C}$ reduces the obtained amount of biochar and also leads to a significant loss of Ctotal and Ntotal contents [18].

Physical and chemical properties of the soil before the experiment, poultry litter (PL), and poultry litter biochar (PLB) are presented in Table 1. The attached (see graphic_abstract) as graphical abstract. In order to obtain biochar, the pretreated material (dried at $70{ }^{\circ} \mathrm{C}$, ground in a laboratory mill, and $4 \mathrm{~mm}$ sieved) was thermally converted at $300{ }^{\circ} \mathrm{C}$ in a combustion chamber for $15 \mathrm{~min}$. A detailed methodology of analyses performed in organic materials and soil before the experiment was presented in the studies of Mierzwa-Hersztek et al. [19, 20].

\subsection{Experiment design}

The following treatments were carried out: $\mathrm{C}$ : control soil without fertilisation; MF: NPK fertilisers; PL+MF: MF + poultry litter in a dose of $5 \mathrm{t} \mathrm{ha}^{-1}$; PLB 2.25+MF: $\mathrm{MF}+$ biochar in a dose of $2.25 \mathrm{tha}^{-1}$; and PLB 5.0+MF: MF + biochar in a dose of $5 \mathrm{t} \mathrm{ha}^{-1}$. The experiment included 3 replicates for each variant. Due to the need to create comparable conditions in the experiment, the same mineral fertilisation was used in all treatments, except control (total component doses): $100 \mathrm{~kg} \mathrm{~N} \mathrm{ha}^{-1}$, $40 \mathrm{~kg} \mathrm{P} \mathrm{ha}{ }^{-1}$, and $120 \mathrm{~kg} \mathrm{~K}^{-1}$. A dose of phosphorus was used once in the form of enriched triple phosphate, before harvesting the first swath. Potassium was used in the form of potassium salt, and nitrogen in the form of ammonium nitrate. The doses of potassium and nitrogen were divided into three equal parts. Organic materials (PL, PLB) and mineral fertilisers were used once in the first year of the experiment (spring 2014) by mixing them with a $0-10-\mathrm{cm}$ layer of soil, and then, the seeds of a grass pasture mixture of Phleum pratense 'Erecta' $15 \%$, Festuca pratensis 'Ardeinia' 10\%, Festuca arundinacea 'Alix' $10 \%$, Lolium perenne 'Victorian' 20\%, Lolium perenne 'Solen' 20\%, Lolium multiflorum 'Gaza' 10\%, Trifolium pratense 'Dajana' 5\%, and Lolium westerwoldicum 'Mowester' $10 \%$ in the amount of $60 \mathrm{~kg} \mathrm{ha}^{-1}$ were sown, and a rolling operation was carried out. The increased sowing of the mixture was aimed at better covering the experiment surface.

\subsection{Soil sampling and analysis}

Soil samples were collected from each plot $\left(1 \mathrm{~m}^{2}\right)$, from the 0 10 -cm soil layer, after the 1 st year (8 months after the application of organic materials) and after the 5 th year (54 months after the application of organic materials), after growing was finished. For chemical and physicochemical analyses, soil samples were dried and $1 \mathrm{~mm}$ sieved. The $\mathrm{pH}$ values were determined electrochemically (CP-505 pH meter), while the EC values conductometrically (CPC-502 conductometer), maintaining the material:water ratio of 1:2.5. The total carbon (Ctotal) and nitrogen (Ntotal) in soil were determined using the CNS analyser (Vario EL Cube, Elementar). Humus compound content was extracted from soil by a mixture of $0.1 \mathrm{~mol} \mathrm{dm}^{-3} \mathrm{Na}_{4} \mathrm{P}_{2} \mathrm{O}_{7}$ solution $+0.1 \mathrm{~mol} \mathrm{dm}^{-3} \mathrm{NaOH}$. Humic acid carbon (Cha) was isolated in the extract of $0.1 \mathrm{~mol} \mathrm{dm}^{-3} \mathrm{Na}_{4} \mathrm{P}_{2} \mathrm{O}_{7}$ solution + $0.1 \mathrm{~mol} \mathrm{dm}^{-3} \mathrm{NaOH}$. In turn, fulvic acid carbon (Cfa) was calculated from the difference between the amount of carbon in the extract (Cext) and the amount of humic acid carbon (Cha) in the extract [21]. The extraction residue - non-hydrolysing carbon (Cnh) - was computed from the difference between the Ctotal and the amount of carbon in the extract [22]. Light absorbance was then measured in the obtained solutions of humic acids at the 
Table 1 Physical and chemical properties of the soil before the experiment, poultry litter (PL), and poultry litter biochar (PLB)

\begin{tabular}{|c|c|c|c|c|}
\hline Determination & Unit & $\begin{array}{l}\text { Soil before the } \\
\text { experiment }\end{array}$ & $\begin{array}{l}\text { Poultry litter } \\
\text { (PL) }\end{array}$ & $\begin{array}{l}\text { Poultry litter biochar } \\
\text { (PLB) }\end{array}$ \\
\hline $1.0-0.1 \mathrm{~mm}$ & $\%$ & 73 & - & - \\
\hline $0.1-0.02 \mathrm{~mm}$ & & 15 & - & - \\
\hline$<0.02 \mathrm{~mm}$ & & 12 & - & - \\
\hline $\mathrm{pH} \mathrm{H} \mathrm{H}_{2} \mathrm{O}$ & - & $6.40 \pm 0.02$ & $7.53 \pm 0.02$ & $8.10 \pm 0.02$ \\
\hline $\mathrm{pH} \mathrm{KCl}$ & - & $5.48 \pm 0.01$ & - & - \\
\hline $\mathrm{EC}$ & $\mathrm{mS} \mathrm{cm} \mathrm{cm}^{-1}$ & $0.029 \pm 0.00$ & $0.049 \pm 0.01$ & $0.092 \pm 0.03$ \\
\hline Dry matter & $\mathrm{g} \mathrm{kg}^{-1}$ & - & $445 \pm 1.0$ & $986 \pm 0.2$ \\
\hline Ctotal & $\mathrm{g} \mathrm{kg}^{-1}$ & $8.87 \pm 0.96$ & $323 \pm 0.3$ & $377 \pm 0.3$ \\
\hline Ntotal & & $0.96 \pm 0.01$ & $24.9 \pm 0.74$ & $26.2 \pm 1.1$ \\
\hline $\mathrm{C}: \mathrm{N}$ ratio & - & 9.24 & 12.97 & 14.39 \\
\hline $\mathrm{P}$ & $\mathrm{g} \mathrm{kg}^{-1}$ & $2.09 \pm 0.06$ & $13.2 \pm 0.36$ & $30.5 \pm 0.31$ \\
\hline K & & $1.66 \pm 0.06$ & $17.8 \pm 0.39$ & $37.3 \pm 2.36$ \\
\hline $\mathrm{Cd}$ & $\mathrm{mg} \mathrm{kg}^{-1}$ & $0.62 \pm 0.02$ & $0.39 \pm 0.01$ & $0.55 \pm 0.03$ \\
\hline $\mathrm{Cr}$ & & $6.97 \pm 0.89$ & $2.82 \pm 0.31$ & $16.4 \pm 0.60$ \\
\hline $\mathrm{Cu}$ & & $5.78 \pm 0.27$ & $16.1 \pm 1.22$ & $57.6 \pm 0.88$ \\
\hline $\mathrm{Pb}$ & & $25.7 \pm 1.58$ & $2.02 \pm 0.20$ & $3.91 \pm 0.61$ \\
\hline $\mathrm{Ni}$ & & $4.13 \pm 0.46$ & $3.42 \pm 0.14$ & $10.8 \pm 0.49$ \\
\hline $\mathrm{Zn}$ & & $136.9 \pm 11.9$ & $111 \pm 5$ & $280 \pm 3$ \\
\hline $\begin{array}{l}\text { Specific surface area } \\
\left(S_{\mathrm{BET}}\right)\end{array}$ & $\mathrm{m}^{2} \mathrm{~g}^{-1}$ & - & $1.83 \pm 0.22$ & $2.76 \pm 0.29$ \\
\hline Pore volume & $\mathrm{cm}^{3} \mathrm{~g}^{-1}$ & - & $0.006 \pm 0.000$ & $0.011 \pm 0.002$ \\
\hline Pore diameter & $\mathrm{nm}$ & - & $14 \pm 2$ & $18 \pm 3$ \\
\hline
\end{tabular}

\pm standard deviation, $n=3$ wavelength of 280, 465, and $665 \mathrm{~nm}$, and the colour ratio (A2/6, $\mathrm{A} 2 / 4$, and $\mathrm{A} 4 / 6$ ) was computed. It has been assumed that the value of A464 determines the absorbance of substances at the initial stage of humification, and A664 determines the absorbance of substances with a high degree of humification [23, 24].

On the basis of Ctotal content (in \%) and volumetric density of soil ( $\rho c$ in $\mathrm{Mg} \mathrm{m}^{-3}$ ), organic carbon stocks $(\mathrm{ZC})$ were calculated after the first and after the fifth year of the experiment at the 0-10-cm soil layer [25]:

$\mathrm{ZC}=$ Ctotal $\rho \mathrm{c} 10\left(\mathrm{Mg} \mathrm{ha}^{-1}\right)$

where $\mathrm{ZC}$ is the soil carbon stock (in $\mathrm{Mg} \mathrm{C}^{-1}$ ), Ctotal is the carbon content (mg C g soil ${ }^{-1}$ ), $\rho c$ is the soil density (bulk density in $\mathrm{Mg} \mathrm{m}^{3}$ ), with depth of the soil layer in $\mathrm{cm}$.

\subsection{Statistical analysis}

The differences between each treatment and the control, as well as between individual treatments, were evaluated using one-way analysis of variance (ANOVA, Duncan's test, $\alpha \leq 0.05$ ). Variation within treatments was determined by calculating the standard deviation $( \pm \mathrm{SD})$ values. All statistical analyses were performed using Statistica PL 13 software (StatSoft Inc.).

\section{Results and discussion}

\subsection{Effect of biochar on boil pH and electrical conductivity}

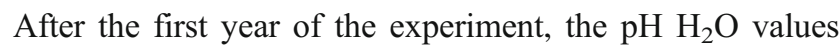
(Table 2) determined in soil with the addition of MF, PLB 2.25+MF, and PLB 5.0+MF were higher compared with the values determined in the $\mathrm{C}$ and $\mathrm{MF}$ treatments. Regardless of the treatment, soil $\mathrm{pH} \mathrm{H}_{2} \mathrm{O}$ values determined after the fifth year of the experiment were smaller compared with the values determined after the first year. Comparison of contents obtained after the first and fifth years of the experiment showed that the $\mathrm{pH}$ value decreased the most in the soil of PLB 2.25+MF (by $13.4 \%$ ) and the least in the soil of the $\mathrm{C}$ treatment (by $1.8 \%)$. A similar trend was found after analysing the $\mathrm{pH}$ values determined in $\mathrm{KCl}$.

The determined values of electrical conductivity (EC) are shown in Table 2. The results obtained allowed to state the increase in the EC values in all treatments after the fifth year of the experiment, regardless of fertilisation applied, compared with the values obtained after the first year. In the $\mathrm{C}, \mathrm{MF}$, and PL+MF treatments, the EC values increased by over $300 \%$, while in the PLB 2.25+MF and PLB 5.0+MF treatments, the 
Table 2 Value of $\mathrm{pH}$ and $\mathrm{EC}$ in soil after 1st year and after 5th years of experiment

\begin{tabular}{|c|c|c|c|c|c|c|}
\hline Treatment & $\begin{array}{l}\text { After the 1st year } \\
\mathrm{pH} \mathrm{H}_{2} \mathrm{O}\end{array}$ & After the 5 th year & $\begin{array}{l}\text { After the 1st year } \\
\mathrm{pH} \mathrm{KCl}\end{array}$ & After the 5 th year & $\begin{array}{l}\text { After the } 1 \text { st year } \\
\mathrm{EC}\left(\mathrm{mS} \mathrm{cm}^{-1}\right)\end{array}$ & After the 5 th year \\
\hline $\mathrm{C}$ & $6.34 \mathrm{e} \pm 0.04$ & $6.22 \mathrm{~d} \pm 0.02$ & $5.52 \mathrm{~d} \pm 0.07$ & $5.30 \mathrm{c} \pm 0.04$ & $0.017 \mathrm{a} \pm 0.001$ & $0.069 \mathrm{c} \pm 0.006$ \\
\hline MF & $6.21 \mathrm{~d} \pm 0.05$ & $5.79 \mathrm{a} \pm 0.06$ & $5.34 c \pm 0.05$ & $4.61 \mathrm{a} \pm 0.04$ & $0.015 \mathrm{a} \pm 0.002$ & $0.070 \mathrm{c} \pm 0.001$ \\
\hline $\mathrm{PL}+\mathrm{MF}$ & $6.48 \mathrm{f} \pm 0.07$ & $6.10 c \pm 0.08$ & $5.90 \mathrm{e} \pm 0.24$ & $4.93 b \pm 0.04$ & $0.020 \mathrm{a} \pm 0.003$ & $0.084 \mathrm{~d} \pm 0.003$ \\
\hline PLB 2.25+MF & $6.97 \mathrm{~g} \pm 0.04$ & $6.03 c \pm 0.09$ & $5.53 \mathrm{f} \pm 0.10$ & $5.29 c \pm 0.07$ & $0.061 b \pm 0.002$ & $0.127 \mathrm{e} \pm 0.007$ \\
\hline PLB 5.0+MF & $6.46 \mathrm{ef} \pm 0.02$ & $5.89 \mathrm{~b} \pm 0.05$ & $5.67 \mathrm{~d} \pm 0.11$ & $4.96 b \pm 0.09$ & $0.023 \mathrm{a} \pm 0.003$ & $0.066 b c \pm 0.007$ \\
\hline
\end{tabular}

\pm standard deviation, $n=3$; means marked with the same letters do not differ significantly according to Duncan's test at $\alpha \leq 0.05$; factor: fertilisation $\times$ year

increase was $109 \%$ and $190 \%$, respectively. These EC values showed that the addition of both doses of biochar caused a much smaller increase in the soil electrical conductivity over a five-year period compared with treatments without biochar. However, it should be noted that the determined EC values did not limit plant growth and development.

Agbna et al. [26] discovered a reduced pH (by 27\%) after applying different doses of wheat straw biochar. These authors also showed that the EC values in soil decreased with increased biochar doses. On the other hand, in their pot experiment, Chan et al. [27] determined increased pH, 6 weeks after biochar application. As stated by the authors, these changes resulted from introducing with biochar a significant load of basic cations. The deacidifying effect of poultry litter biochar and increased soil EC were demonstrated by Sikder and Joardar [28].

\subsection{Effect of biochar on Ntotal and Ctotal content}

According to Lehmann [10], the addition of biochar to soil can affect Ntotal retention in soil and thus limit its leaching to groundwater. The analysis of Ntotal content in soil (Table 3) obtained after the first and fifth years of experiment allows observing an increase in Ntotal content in all treatments. However, the largest increase in Ntotal content (by 12\%) was found in PLB 2.25+MF. Ntotal content obtained in the PLB 2.25+MF soil was 4\% higher after the first year and $13 \%$ higher after the fifth year than that in the $\mathrm{C}$ treatment. Ntotal contents obtained in the PLB 5.0+MF treatments were slightly smaller than those in the control, while the smallest contents after both the first and fifth years of experiment were determined in MF treatment. However, it should be emphasised that the experiment involved supplementary $\mathrm{N}$ fertilisation in the amount of $100 \mathrm{~kg} \mathrm{~N} \mathrm{ha}^{-1}$ for each treatment, except for $\mathrm{C}$ treatment. Moreover, the perennial grass mixture yield ( $\mathrm{N}$ uptake), which was collected from each treatment, played a large role in the $\mathrm{N}$ cycle. The study of Zhan et al. [29] revealed increased total carbon content by $27.6 \%$ and Ntotal content by $75.6 \%$ in soil amended with rice straw biochar after the fourth year of the experiment. The mechanism of increasing the $\mathrm{C}$ and $\mathrm{N}$ contents concerns mainly the difficult to degrade compounds of both elements that are present in $\mathrm{BC}$ and, therefore, the long residence of $\mathrm{BC}$ in the soil. In the case of nitrogen, there may be a risk of its protenisation; i.e., microorganisms may build up in the protein structures of the microorganisms, so that $\mathrm{N}$ is not taken up or leached from the soil.

In our study, Ctotal (Table 3) after the first year of the experiment ranged from 8.67 (MF) to $9.90 \mathrm{~g} \mathrm{~kg}^{-1}$ DM (PLB $2.25+\mathrm{MF})$. After the fifth year of the experiment, regardless of the fertilisation applied, the Ctotal contents increased significantly compared with those obtained after the first year. The highest (13.62 $\left.\mathrm{g} \mathrm{kg}^{-1} \mathrm{DM}\right)$ contents after 5 years were determined in PL+MF, and the Ctotal increase over these 5 years was $53.2 \%$. The lowest Ctotal content (10.95 $\left.\mathrm{g} \mathrm{kg}^{-1} \mathrm{DM}\right)$ was found in the treatment with only MF treatment applied. The study showed that the Ctotal contents in the soil of PL+MF, PLB 2.25+MF, and PLB 5.0+MF after the fifth year of the experiment were significantly higher than those in the $\mathrm{C}$ and MF treatments. In the results presented by Agbna et al. [26], the Ctotal content in treatments with different doses of biochar was 1.2 to $1.7 \%$ higher compared with that in the $\mathrm{C}$ treatment. Abbasi and Anwar [30] observed an increase in carbon content by $82 \%$ after applying $30 \mathrm{t} \mathrm{ha}^{-1}$ of PLB. On the other hand, the study of Bhattarai et al. [31] revealed a $35 \%$ increase in Ctotal content after applying $10 \mathrm{tha}^{-1}$ of PLB. The results presented by Sikder and Joardar [28] indicate an increase in Ctotal content by $55 \%$ after the application of $5 \mathrm{t} \mathrm{ha}^{-1}$ of PL, by $47 \%$ after applying $2 \mathrm{t} \mathrm{ha}^{-1}$ of PLB, and by $100 \%$ when $4 \mathrm{tha}^{-1}$ dose of PLB was used. In our study, the highest Ctotal content after the fifth year of the experiment was determined in the treatment fertilised with PL. In the study of Juriga et al. [32], the Ctotal content in soil increased significantly after the addition of biochar in a dose of $20 \mathrm{t} \mathrm{ha}^{-1}$, which is several times higher than doses used in our study.

The $\mathrm{C}: \mathrm{N}$ ratio is a value that reflects the organic matter humification level. Bednarek et al. [33] showed that the organic matter decomposition was faster when the Ctotal to Ntotal ratio value was lower. It resulted from the higher content of $\mathrm{N}$ which is a building component of microbial biomass. After the first year of the experiment, the $\mathrm{C}: \mathrm{N}$ ratio values 
Table 3 The content of Ntotal and Ctotal in soil and C:N ratio after the 1st and 5th years of the experiment

\begin{tabular}{lllllll}
\hline Treatment & $\begin{array}{l}\text { After the 1st year } \\
\text { Ntotal }\left(\mathrm{g} \mathrm{kg}^{-1} \mathrm{DM}\right)\end{array}$ & After the 5th year & $\begin{array}{l}\text { After the 1st year } \\
\text { Ctotal }\left(\mathrm{g} \mathrm{kg}^{-1} \mathrm{DM}\right)\end{array}$ & After the 5th year & $\begin{array}{l}\text { After the 1st year } \\
\text { C:N }\end{array}$ & After the 5th year \\
\hline $\mathrm{C}$ & $1.09 \mathrm{~b} \pm 0.04$ & $1.12 \mathrm{bc} \pm 0.06$ & $9.61 \mathrm{~b} \pm 0.12$ & $10.77 \mathrm{c} \pm 0.40$ & $8.82 \mathrm{a} \pm 0.16$ & $9.62 \mathrm{~cd} \pm 0.47$ \\
$\mathrm{MF}$ & $0.96 \mathrm{a} \pm 0.05$ & $1.06 \mathrm{~b} \pm 0.03$ & $8.67 \mathrm{a} \pm 0.13$ & $10.95 \mathrm{c} \pm 0.20$ & $9.03 \mathrm{ab} \pm 0.31$ & $10.33 \mathrm{~cd} \pm 0.35$ \\
$\mathrm{PL}+\mathrm{MF}$ & $1.11 \mathrm{bc} \pm 0.04$ & $1.20 \mathrm{~cd} \pm 0.08$ & $8.89 \mathrm{a} \pm 0.11$ & $13.62 \mathrm{e} \pm 0.46$ & $8.01 \mathrm{a} \pm 0.26$ & $11.35 \mathrm{~d} \pm 0.74$ \\
PLB 2.25+MF & $1.13 \mathrm{bc} \pm 0.06$ & $1.26 \mathrm{~d} \pm 0.05$ & $9.90 \mathrm{~b} \pm 0.14$ & $11.72 \mathrm{~d} \pm 0.15$ & $8.76 \mathrm{a} \pm 0.07$ & $9.30 \mathrm{bc} \pm 0.48$ \\
PLB 5.0+MF & $1.08 \mathrm{~b} \pm 0.03$ & $1.10 \mathrm{~b} \pm 0.02$ & $9.59 \mathrm{~b} \pm 0.17$ & $11.54 \mathrm{~d} \pm 0.12$ & $8.88 \mathrm{a} \pm 0.33$ & $10.49 \mathrm{bc} \pm 0.25$ \\
\hline
\end{tabular}

\pm standard deviation, $n=3$; means marked with the same letters do not differ significantly according to Duncan's test at $\alpha<0.05$; factor: fertilisation $\times$ year

(Table 3) ranged from 8.01 in PL+MF to $9.03 \mathrm{~g} \mathrm{~kg}^{-1} \mathrm{DM}$ in $M F$. The highest $C: N$ ratio value in a MF treatment may result from more available $\mathrm{N}$ forms. Significantly higher $\mathrm{C}: \mathrm{N}$ ratios in soil of all fertilised treatments after the fifth year of the experiment than after the first year indicate a slight slowdown in the SOM decomposition despite a significant increase in the Ctotal content. It is assumed that a $\mathrm{C}: \mathrm{N}$ ratio below 20 indicates good conditions for the organic matter mineralisation and thus high biological activity at the organic level. The Ctotal content increase observed in all treatments is natural for permanent pasture; however, its significant increase in the PL+MF treatment in our experiment (after 5 years) may result from greater changes in soil physical properties than in other treatments with fertilisation applied. Better aeration of the soil and improved air-water ratios in this treatment could favour the mineralisation process. According to BlancoCanqui [34], the use of biochar has a significant effect on improving the physical properties of soil, including its structure, porosity, and density. Improved soil properties directly affect plant growth and yielding, as they cause increased availability of air and water in roots. Under the influence of biochar fertilisation, the root mass also increases significantly and, once mineralised, it additionally increases the $\mathrm{C}$ pool in the soil [35]. The activity of soil microorganisms is also greater, creating favourable conditions for further mineralisation [36].

\subsection{Effect of biochar on $\mathrm{C}$ extracted with $\mathrm{Na}_{4} \mathrm{P}_{2} \mathrm{O}_{7}+\mathrm{NaOH}, \mathrm{C}$ humic acid, $\mathrm{C}$ fulvic acid, and $\mathrm{C}$ non-hydrolysing content}

The extracted carbon contents (Cext) after the first year of the experiment ranged from 5.70 to $6.37 \mathrm{~g} \mathrm{~kg}^{-1} \mathrm{DM}$ and, after the fifth year, from 5.39 to $7.82 \mathrm{~g} \mathrm{~kg}^{-1} \mathrm{DM}$ (Table 4). Comparing the results obtained after the first year and the fifth year of the experiment, it was found that the Cext content significantly increased in treatments fertilised with PL+MF (by 4\%) and PLB 5.0+MF (by 19\%). However, it should be noted that this fraction is represented by simpler organic compounds with low molecular weight, which are most labile in soil and susceptible to mineralisation.
The humic acid carbon (Cha) contents determined in soil after the first year of the experiment ranged from 1.85 (C) to $2.74 \mathrm{~g} \mathrm{~kg}^{-1} \mathrm{DM}$ (PLB 2.25+MF) (Table 4). After the fifth year of the experiment, a significant increase in the Cha content was also found in the PL treatment (by 17\%). In turn, the Cha contents in C, PLB 2.25+MF, and PLB 5.0+MF after the fifth year were lower than those determined after the first year, by $32 \%, 45 \%$, and $28 \%$, respectively. The reduced Cha content may indicate the transformation of this carbon fraction into more complex compounds with lower mobility [21]. On the other hand, the reduced Cha content may be due to the use of this carbon fraction by microorganisms or its displacement to deeper layers of the soil profile. Our study revealed a significant effect of the used poultry litter on increasing the Cha content compared with the treatment in which only mineral fertilisation was used.

The Cfa contents determined after the first year of the experiment ranged from 3.26 to $4.03 \mathrm{~g} \mathrm{~kg}^{-1} \mathrm{DM}$ and, after the fifth year, from 3.52 to $5.85 \mathrm{~g} \mathrm{~kg}^{-1} \mathrm{DM}$ (Table 4). Comparing the Cfa contents obtained after the first and fifth years of the experiment, their significant increase was observed in treatments with the addition of biochar: in PLB $2.25+\mathrm{MF}$ by $15 \%$ and in PLB 5.0+MF by $34 \%$. However, in the MF and PL treatments, the Cfa contents slightly decreased. The Cfa contents in all treatments were higher that the Cha contents, both after the first and fifth years of the experiment. Cfa content are easily soluble in water, and this determines their mobility and ability to move deeper into the soil profile. Greater Cfa contents may lead, among others, to faster leaching of heavy metals and alkaline cations from soil (distribution of complex metal connections with humic substances) [7].

The Cnh contents after the first year of the experiment ranged from 2.59 (PL+MF) to $3.91 \mathrm{~g} \mathrm{~kg}^{-1} \mathrm{DM}$ (C and PLB 2.25+MF) and, after the fifth year, from 3.72 (PLB 5.0+MF) to $7.07 \mathrm{~g} \mathrm{~kg}^{-1} \mathrm{DM}$ (PL+MF) (Table 4). In our study, after the fifth year of the experiment, the $\mathrm{Cnh}$ content significantly increased in each of the treatments and regardless of the fertilisation applied. The increase in Cnh content after 5 years in individual treatments was $27 \%$ for $\mathrm{C}, 49 \%$ for $\mathrm{MF}, 63 \%$ for $\mathrm{PL}+\mathrm{MF}, 35 \%$ for PLB $2.25+\mathrm{MF}$, and $13 \%$ for PLB 5.0+MF. 
Table 4 The organic carbon content in soil and humus compound fraction

\begin{tabular}{|c|c|c|}
\hline Treatment & After the 1st year & After the 5 th year \\
\hline \multicolumn{3}{|l|}{$\operatorname{Cext}\left(\mathrm{g} \mathrm{kg}^{-1} \mathrm{DM}\right)$} \\
\hline $\mathrm{C}$ & $5.70 \mathrm{ab} \pm 0.16$ & $5.39 a \pm 0.30$ \\
\hline MF & $6.03 b c \pm 0.13$ & $5.79 \mathrm{ab} \pm 0.35$ \\
\hline $\mathrm{PL}+\mathrm{MF}$ & $6.29 \mathrm{~cd} \pm 0.32$ & $6.55 \mathrm{~d} \pm 0.16$ \\
\hline PLB 2.25+MF & $5.99 b c \pm 0.23$ & $5.72 \mathrm{ab} \pm 0.21$ \\
\hline PLB 5.0+MF & $6.37 \mathrm{~cd} \pm 0.06$ & $7.82 \mathrm{e} \pm 0.19$ \\
\hline \multicolumn{3}{|l|}{ Cha $\left(\mathrm{g} \mathrm{kg}^{-1} \mathrm{DM}\right)$} \\
\hline $\mathrm{C}$ & $1.85 b \pm 0.10$ & $1.40 \mathrm{a} \pm 0.09$ \\
\hline MF & $2.00 \mathrm{~b} \pm 0.00$ & $2.07 b \pm 0.27$ \\
\hline $\mathrm{PL}+\mathrm{MF}$ & $2.52 \mathrm{c} \pm 0.11$ & $3.03 \mathrm{~d} \pm 0.17$ \\
\hline PLB $2.25+\mathrm{MF}$ & $2.74 c \pm 0.10$ & $1.89 b \pm 0.07$ \\
\hline PLB 5.0+MF & $2.52 \mathrm{c} \pm 0.10$ & $1.97 b \pm 0.02$ \\
\hline \multicolumn{3}{|l|}{$\mathrm{Cfa}\left(\mathrm{g} \mathrm{kg}^{-1} \mathrm{DM}\right)$} \\
\hline $\mathrm{C}$ & $3.85 b c \pm 0.05$ & $3.99 c \pm 0.23$ \\
\hline MF & $4.03 c \pm 0.11$ & $3.73 b c \pm 0.20$ \\
\hline $\mathrm{PL}+\mathrm{MF}$ & $3.78 b c \pm 0.16$ & $3.52 \mathrm{ab} \pm 0.29$ \\
\hline PLB 2.25+MF & $3.26 \mathrm{a} \pm 0.11$ & $3.83 b c \pm 0.28$ \\
\hline PLB 5.0+MF & $3.86 b c \pm 0.13$ & $5.85 \mathrm{~d} \pm 0.21$ \\
\hline \multicolumn{3}{|l|}{$\mathrm{Cnh}\left(\mathrm{g} \mathrm{kg}^{-1} \mathrm{DM}\right)$} \\
\hline $\mathrm{C}$ & $3.91 \mathrm{c} \pm 0.10$ & $5.38 \mathrm{~d} \pm 0.10$ \\
\hline MF & $2.64 \mathrm{a} \pm 0.03$ & $5.15 \mathrm{~d} \pm 0.27$ \\
\hline $\mathrm{PL}+\mathrm{MF}$ & $2.59 \mathrm{a} \pm 0.27$ & $7.07 \mathrm{f} \pm 0.45$ \\
\hline PLB $2.25+\mathrm{MF}$ & $3.91 \mathrm{c} \pm 0.28$ & $6.01 \mathrm{e} \pm 0.09$ \\
\hline PLB 5.0+MF & $3.22 b \pm 0.17$ & $3.72 \mathrm{c} \pm 0.30$ \\
\hline
\end{tabular}

\pm standard deviation, $n=3$; means marked with the same letters do not differ significantly according to Duncan's test at $\alpha<0.05$; factor: fertilisation $\times$ year

Based on the results obtained, it can be stated that fertilisation with PL and PLB in a dose of $2.25 \mathrm{t} \mathrm{ha}^{-1}$ in conjunction with MF had the greatest effect on the Cnh contents.

\subsection{Biochar effect on the value of humic to fulvic acid ratio and the optical properties of humic acid}

The Cha:Cfa ratio is one of the basic indicators to assess the quality of soil organic matter and, above all, its stability. It is generally accepted that higher Cha:Cfa ratio values are typical for more fertile soils [37]. Changes in the carbon content in humic and fulvic acids after fertilisation consequently altered the Cha:Cfa ratio value (Table 5). The results obtained after the first year prove that soil in treatments with organic materials had significantly higher Cha:Cfa ratios than the soil from the $\mathrm{C}$ treatment and MF treatment. The results also indicate that the fertilisation applied increased the Cha:Cfa ratio in most treatments (MF, PL+MF, and PLB 2.25+MF) after the fifth year of the experiment and, in others, did not affect this
Table 5 Value of the Cha:Cfa ratio, A4/6, A2/4, and A2/6

\begin{tabular}{|c|c|c|}
\hline Treatment & After the 1st year & After the 5 th year \\
\hline \multicolumn{3}{|l|}{ Cha:Cfa } \\
\hline $\mathrm{C}$ & $0.48 b \pm 0.03$ & $0.35 \mathrm{a} \pm 0.01$ \\
\hline MF & $0.50 \mathrm{~b} \pm 0.02$ & $0.56 b \pm 0.07$ \\
\hline $\mathrm{PL}+\mathrm{MF}$ & $0.67 \mathrm{c} \pm 0.00$ & $0.87 \mathrm{~d} \pm 0.11$ \\
\hline PLB 2.25+MF & $0.89 \mathrm{~d} \pm 0.04$ & $0.50 \mathrm{~b} \pm 0.05$ \\
\hline PLB 5.0+MF & $0.70 \mathrm{c} \pm 0.06$ & $0.34 \mathrm{a} \pm 0.02$ \\
\hline \multicolumn{3}{|l|}{$\mathrm{A} 4 / 6$} \\
\hline $\mathrm{C}$ & $5.00 \mathrm{ab} \pm 0.05$ & $4.26 \mathrm{a} \pm 0.27$ \\
\hline MF & $4.84 \mathrm{ab} \pm 0.22$ & $4.83 \mathrm{ab} \pm 0.33$ \\
\hline $\mathrm{PL}+\mathrm{MF}$ & $5.04 b \pm 0.06$ & $4.97 b \pm 0.52$ \\
\hline PLB 2.25+MF & $5.16 b \pm 0.10$ & $5.05 b \pm 0.72$ \\
\hline PLB 5.0+MF & $4.85 \mathrm{ab} \pm 0.25$ & $5.37 b \pm 0.67$ \\
\hline \multicolumn{3}{|l|}{$\mathrm{A} 2 / 4$} \\
\hline $\mathrm{C}$ & $0.79 a \pm 0.03$ & $1.53 \mathrm{bc} \pm 0.02$ \\
\hline MF & $0.87 \mathrm{a} \pm 0.09$ & $1.59 \mathrm{c} \pm 0.07$ \\
\hline $\mathrm{PL}+\mathrm{MF}$ & $0.78 \mathrm{a} \pm 0.03$ & $1.35 b \pm 0.14$ \\
\hline PLB $2.25+\mathrm{MF}$ & $0.77 \mathrm{a} \pm 0.03$ & $1.49 b c \pm 0.23$ \\
\hline PLB 5.0+MF & $0.76 \mathrm{a} \pm 0.04$ & $1.67 \mathrm{c} \pm 0.12$ \\
\hline \multicolumn{3}{|l|}{$\mathrm{A} 2 / 6$} \\
\hline $\mathrm{C}$ & $3.97 \mathrm{a} \pm 0.17$ & $6.52 b \pm 0.33$ \\
\hline MF & $4.23 a \pm 0.61$ & $7.69 \mathrm{c} \pm 0.66$ \\
\hline $\mathrm{PL}+\mathrm{MF}$ & $3.91 \mathrm{a} \pm 0.17$ & $6.66 \mathrm{~b} \pm 0.09$ \\
\hline PLB 2.25+MF & $3.96 \mathrm{a} \pm 0.22$ & $7.42 c \pm 0.32$ \\
\hline PLB 5.0+MF & $3.67 \mathrm{a} \pm 0.01$ & $8.91 \mathrm{~d} \pm 0.54$ \\
\hline
\end{tabular}

\pm standard deviation, $n=3$; means marked with the same letters do not differ significantly according to Duncan's test at $\alpha<0.05$; factor: fertilisation $\times$ year

ratio at all. The analysis of changes in the Cha:Cfa ratio in the experiment revealed that the most beneficial effect on improving the organic matter quality after 5 years had treatment with the addition of poultry litter, where a significant increase in Cha:Chf (by 23\% compared with 2014) was noted. Although the Cha:Cfa values obtained did not exceed 1 in any of the fertiliser variants, the highest rate of organic matter humification in the soil was determined in the PL treatment in conjunction with MF, confirming earlier study results.

Kononowa [21] argued that the A4/6 quotient values greater than 5 indicate a simpler structure of humic acids and their greater mobility. The obtained A4/6 quotient values after the first year and after the fifth year of the experiment were comparable and ranged from 4.83 to 5.37 (Table 5). The applied fertilisation had no significant effect on this value after 1 year. On the other hand, statistical analysis of the A4/6 quotient value after the fifth year of the experiment showed that fertilisation with organic materials significantly increased this value compared with the control. 
Fig. 2 Soil carbon stocks after the 1 st and 5 th years of the experiment

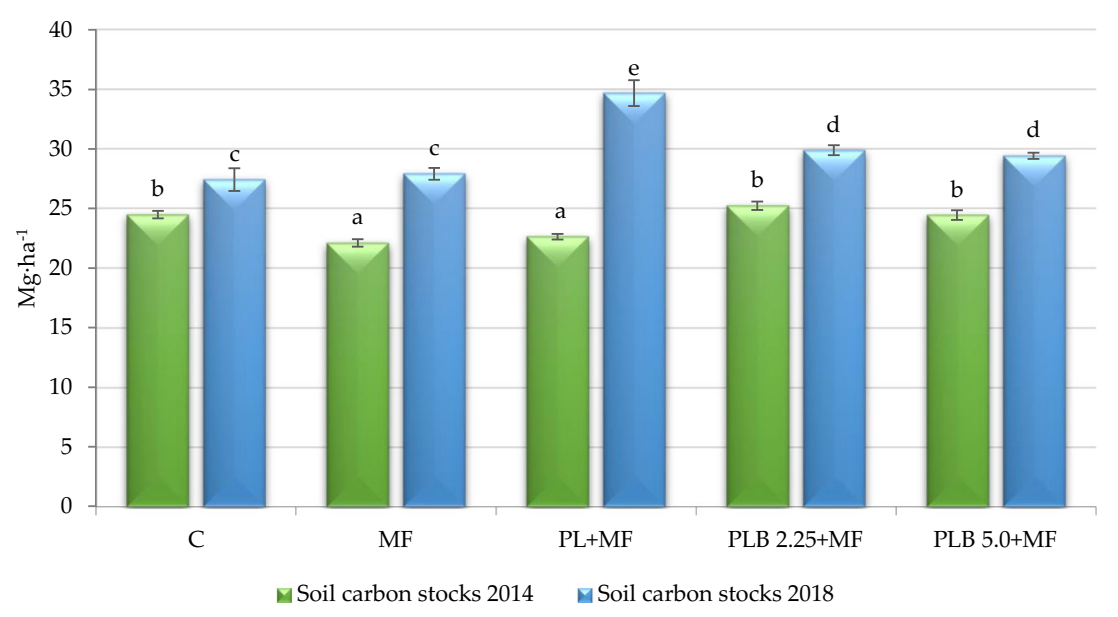

The A2/4 quotient presents the ratio of humificationresistant substances to substances at the initial decomposition stage, and a significant increase in its value was observed in all treatments after 5 years of the experiment. After 1 year, the highest A2/4 quotient (0.87) was found in MF, while the lowest in PLB 5.0+MF (0.76). After 5 years, the highest A2/4 quotient was found in PLB 5.0+MF (1.67), while the lowest in PL+MF (1.35).

The ratio of the content of substances difficult to humidify to the content of substances characterised by an advanced degree of humification is presented as the A2/6 ratio (Table 5). In the analysed soil, the quotient values after the first year of the experiment ranged from 3.67 in PLB 5.0+MF to 4.23 in MF. After the fifth year of the experiment, a significant increase in the A2/6 ratio was found in all treatments. The highest increase of $59 \%$ was observed in PLB 5.0+MF, and the smallest of $39 \%$ in the control. Dębska [37] stated that the organic matter in the soil, where natural fertilisation was applied in the form of slurry, was characterised by a higher Cha:Cfa ratio. Additionally, humic acids had higher values of absorbance coefficients than organic matter of soil with only mineral fertilisation applied.

The results showed that the rate of transformation and humification of organic matter decreased to the greatest extent in treatments amended with PLB 5.0+MF after 5 years of the experiment. The mineralisation of organic matter was the fastest in the PL+MF treatment. As reported by Wang et al. [38], apart from providing a carbon-resistant fraction, biochar indirectly affects $\mathrm{C}$ sequestration by reducing the intensity of transformations leading to SOM degradation, at least for several years after its application.

\subsection{Carbon stocks in soil}

Organic carbon stocks (SCS) in soil are conditioned by many factors, such as climate, soil properties, cultivation type, fertilisation type, irrigation, or the type and frequency of agro-technical operations performed [39]. Our results indicated an increase in SCS values after 5 years of the experiment (Fig. 2). The most beneficial effect on the SCS increase was observed in the PL+MF treatment where the parameter value increased by $34.7 \%$ after the fifth year. It should also be emphasised that the SCS values in PL+MF, PLB $2.25+\mathrm{MF}$, and PLB 5.0+MF after the fifth year of the experiment were significantly higher than in $\mathrm{C}$ and $\mathrm{MF}$ treatments.

When considering the issue of the SOC increase, not only the type of fertilisation applied but also environmental factors should be taken into account. Given that the organic materials were applied only once (in 2014) in the experiment, it is difficult to clearly conclude on their individual/exclusive impact on the SOC content increase after 5 years. According to Zeraatpishe and Khormali [40], climate and, above all, soil moisture conditions are the most important environmental factors affecting SOC content. In addition, these authors also indicate the mineral composition and soil structure as factors stabilising the SOC content. Dignac et al. [41] also emphasised the important role of plants and soil macro- and microorganisms that can significantly affect the organic matter mineralisation rate. According to the cited authors, the type and number of agro-technical operations, including fertilisation, are also significant. Comparing our results with determinants of the increased SOC contents described in the literature, one can state the indirect effect of the organic materials applied on the rate and direction of biochemical processes in the soil, which, in turn, led to an increase in the $\mathrm{C}$ content in the soil.

\section{Summary}

The conducted experiment proved that the fertilisation with $\mathrm{PLB}+\mathrm{MF}$ reduced the organic matter transformation rate. The process of organic matter mineralisation was the most intensive in the soil with the addition of PL, proving that this material can, in a relatively short time, significantly increase the SOC content. Unfortunately, due to the rapid decomposition 
of PL, this effect may be of short duration in contrast to treatments where PLB was applied. Determined A4/6 quotient values showed that PLB had a more favourable effect on the structure durability and lower mobility of Cha compared with poultry litter. It was shown that in both the 1 st and 5 th years of the experiment, the use of PLB in a lower dose $\left(2.25 \mathrm{tha}^{-1}\right)$ was more beneficial for increasing the pool of $\mathrm{Cnh}$, compared with the treatment where PLB was used in a higher dose $\left(5.0 \mathrm{t} \mathrm{ha}^{-1}\right)$. The addition of PL and PLB to the soil significantly increased the SOC contents. Our study showed that the identification of changes that may occur in the quantitative and qualitative composition of soil humus after the application of poultry litter biochar may be helpful in determining the appropriate biochar dose in the future.

Funding The research was financed by the Ministry of Science and Higher Education of the Republic of Poland.

Open Access This article is licensed under a Creative Commons Attribution 4.0 International License, which permits use, sharing, adaptation, distribution and reproduction in any medium or format, as long as you give appropriate credit to the original author(s) and the source, provide a link to the Creative Commons licence, and indicate if changes were made. The images or other third party material in this article are included in the article's Creative Commons licence, unless indicated otherwise in a credit line to the material. If material is not included in the article's Creative Commons licence and your intended use is not permitted by statutory regulation or exceeds the permitted use, you will need to obtain permission directly from the copyright holder. To view a copy of this licence, visit http://creativecommons.org/licenses/by/4.0/.

\section{References}

1. Krasowicz S, Oleszek W, Horabik J, Debicki R, Jankowiak J, Stuczyński T, Jadczyszyn J (2011) Rational management of soil environment (in Polish). Pol J Agron 7:43-58

2. GUS Available online: bdl.stat.gov.pl/BDL/dane/podgrup/tablica (accessed on 1 April 2020)

3. Augustyńska-Prejsnar A, Ormian M, Sokołowicz Z, Topczewska J, Lechowska J (2018) Environmental impacts of pig and poultry farms (in polish). Proc ECOpole 12(1):107-115

4. Malińska K (2012) Biochar- a response to current environmental issues (in Polish). Eng Environ Protect 15(4):387-403

5. Draper K, Tomlinson T (2012) Poultry litter biochar- a US perspective. International Biochar Initiative (IBI). http://www.biocharinternational.org/sites/default/files/Poultry_litter_final_2012.pdf. Accessed 25 February 2020

6. Shakya A, Agarwal T (2017) Poultry litter biochar: an approach towards poultry litter management - a review. Int J Curr Microbiol App Sci 6(10):2657-2668

7. Mierzwa-Hersztek M, Gondek K, Kopeć M, Ukalska-Jaruga A (2018) Biochar changes in soil based on quantitative and qualitative humus compounds parameters. Soil Sci Annu 69(4):234-242

8. Kameyama K, Miyamoto T, Shiono T, Shinogi Y (2011) Influence of sugarcane bagasse-derived biochar application on nitrate leaching in calcaric dark red soil. J Environ Qual 41:1131-1137. https://doi.org/10.2134/jeq2010.0453

9. Wei Z, Wang JJ, Hernandez AB, Warren A, Park JH, Meng Y, Dodla SK, Jeong C (2019) Effect of biochar amendment on sorption-desorption and dissipation of $17 \alpha$ ethinylestradiol in sandy loam and clay soils. Sci Total Environ 686:959-967. https://doi. org/10.1016/j.scitotenv.2019.06.050

10. Lehmann J (2007) Bio-energy in the black. Front Ecol Environ 5(7):381-387

11. Verheijen FGA, Jeffery S, Bastos AC, van der Velde M, Diafas I (2010) Biochar application to soils - a critical scientific review of effects on soil properties, Process and Functions. European Commission. ISBN: 9789279142932

12. Malińska K, Dach J (2015) Biochar as a supplementary material for biogas production (in polish). Ecol Eng 41:117-124

13. Jeffery S, Bezemer T, Cornelissen G, Kuypertw TW, Lehmann J, Mommer L, Sohi S, Van De Voorde T, Wardle D, Van Groenigen J (2015) The way forward in biochar research: targeting trade offs between the potential wins. GCB Bioenergy 7:1-13

14. Yusof MRM, Ahmed OH, King WS, Zakry FAA (2015) Effects of biochar and chicken litter ash on selected soilchemical properties and nutrients uptake by Oryza sativa L. var. Int J Biosci 6(3):360 369

15. Tisserant A, Cherubini F (2019) Potentials, limitations, co-benefits, and trade-offs of biochar applications to soils for climate change mitigation. Land 8:179. https://doi.org/10.3390/land8120179

16. Gondek K, Mierzwa-Hersztek M (2016) Effect of low-temperature biochar derived from pig manure and poultry litter on mobile and organic matter-bound forms of $\mathrm{Cu}, \mathrm{Cd}, \mathrm{Pb}$ and $\mathrm{Zn}$ in sandy soil. Soil Use Manag 32:357-367

17. Al-Wabel A-OA, El-Naggar AH, Nadeem M, Usman ARA (2013) Pyrolysis temperature induced changes in characteristics and chemical composition of biochar produced from conocarpus wastes. Bioresour Technol 131:374-379

18. Song W, Guo M (2012) Quality variations of poultry litter biochars generated at different pyrolysis temperatures. J Anal Appl Pyrolysis 94:138-145

19. Mierzwa-Hersztek M, Gondek K, Baran A (2016) Effect of poultry litter biochar on soil enzymatic activity, ecotoxicity and plant growth. Appl Soil Ecol 105:144-150

20. Mierzwa-Hersztek M, Klimkowicz-Pawlas A, Gondek K (2018) Influence of poultry litter and poultry litter biochar on soil microbial respiration and nitrifying bacteria activity. Waste Biom Valor 9: 379-389

21. Kononowa M (1968). Soil organic substances, their structure, properties and test methods (in Polish), Translate L. Kuszelewski, A. Żurawska-Tomczyk, PWRiL, State Agricultural and Forestry Publishing House, Warsaw pp 390

22. Gondek K, Mierzwa M (2014) Quantity and quality of organic matter in soil after application of various organic materials. Ecol Chem Eng 21(3):477-485

23. Gonet S (2003) Humus, humic substances, organic carbon - definitions. In: Dębska B, Gonet S (eds) Comments and determination methods, (in polish) in: Humus substances in soils and fertilizers. Wroclaw, PTSH, pp 15-23

24. Kondratowicz-Maciejewska K, Kobierski M, Zdrodowski T (2011) Effect of soil management practices in orchards and cultivated fields on selected properties of humus substances. Pol J Soil Sci 42:167-176

25. Guo LB, Gifford RM (2002) Soil carbon stocks and land use change: a meta analysis. Glob Chang Biol 8(4):345-360

26. Agbna GHD, Ali AAS, Elbashier MMA, Bakir M, Osman A, Elshaikh AEA (2017) Effect of biochar on some soil properties and tomato growth under saline water. Int J Sci Eng Res 8(4):24-28

27. Chan KY, Van Zwieten L, Meszaros I, Downie A, Joseph S (2008) Using poultry litter biochars as soil amendments. Austral J Soil Res 246(5):437-444

28. Sikder S, Joardar JC (2018) Biochar production from poultry litter as management approach and effects on plant growth. Int J Rec Org Waste Agric 8:47-58 
29. Zhan X, Peng J, Wang Y, Liu Y, Chen K, Han X, Wang H, Lin W, Li X (2015) Influences of application of biochar and biochar-based fertilizer on brown soil physiochemical properties and peanut yields. J Plant Nut Fertiliz 21(6):1633-1641

30. Abbasi MK, Anwar AA (2015) Ameliorating effects of biochar derived from poultry manure and white clover residues on soil nutrient status and plant growth promotion-greenhouse experiments. PLoS One 10(6):e0131592. https://doi.org/10.1371/ journal.pone. 0131592

31. Bhattarai B, Neupane J, Dhakal SP, Nepal J, Gnyawali B, Timalsina R, Poudel A (2015) Effect of biochar from different origin on physio-chemical properties of soil and yield of garden pea (Pisum sativum L.) at Paklihawa, Rupandehi, Nepal. World J Agric Res 3(4):129-138

32. Juriga M, Šimanský V, Horák J, Kondrlová E, Igaz D, Polláková N, Buchkina N, Balashov E (2018) The effect of different rates of biochar and biochar in combination with $\mathrm{n}$ fertilizer on the parameters of soil organic matter and soil structure. J Ecol Eng 19(6):153161

33. Bednarek R, Dziadowiec H, Pokojska U, Prusinkiewicz Z (2004) Ecological and soil science research. Publishing house: PWN, Warsaw, p 344 ISBN: 83-01-14216-2

34. Blanco-Canqui H (2017) Biochar and soil physical properties. Soil Sci Soc Am J 81:687-711

35. Hammes K, Schmidt MWI (2009) Changes in biochar in soils. In: Lehmann M, Joseph S (eds) Biochar for environmental management science and technology. Earthscan, London, pp 169-182
36. Kosobucki P, Buszewski B (2014) Natural organic matter in ecosystems - a review. Nova Biotechnol Chem 13-2:109-129

37. Dębska B (2004) Properties of humic substances of soil fertilized with slurry. Dissertation. ATR Bydgoszcz. No. 110, pp.112. (in polish)

38. Wang H, Xu J, Liu X, Zhang D, Li L, Li W (2019) Sheng, L. Effect of long-term application of organic fertilizer on improving organic matter content and retarding acidity in red soil from China. Soil Tillage Res 195:104382

39. Garcia-Pausas, Rabissi A, Rovira P, Romanya J (2017) Organic fertilization increases $\mathrm{C}$ and $\mathrm{N}$ stocks and reduces soil organic matter stability in mediterranean vegetable gardens. Land Degrad Dev 28(2):691-698

40. Zeraatpishe M, Khormali F (2012) Carbon stock and mineral factors controlling soil organic carbon in a climatic gradient, Golestan province. J Soil Sci Plant Nutr 12(4):637-654

41. Dignac M, Derrien D, Barré P, Barot S, Cécillon L, Chenu C, Chevallier T, Freschet GT, Garnier P, Guenet B, Hedde M, Klumpp K, Lashermes G, Maron P-A, Nunan N, Roumet C, Basile-Doelsch I (2017) Increasing soil carbon storage: mechanisms, effects of agricultural practices and proxies. A review. Agron Sustain Dev 37:14. https://doi.org/10.1007/s13593-0170421-2

Publisher's Note Springer Nature remains neutral with regard to jurisdictional claims in published maps and institutional affiliations. 